\title{
Epidemiology of feline immunodeficiency virus and feline leukemia virus in a veterinary teaching hospital
}

Epidemiologia do vírus da imunodeficiência felina e do vírus da leucemia felina em um hospital veterinário universitário

\section{Viviane Rodolfo Barros ${ }^{1}$, José Artur Brilhante Bezerra ${ }^{2} *$, Mariana Silva Bochnakian ${ }^{3}$, Valéria Veras de Paula ${ }^{4}$, Kilder Dantas Filgueira ${ }^{5}$}

RESUMO: O vírus da imunodeficiência felina (FIV) e o vírus da leucemia felina (FeLV) são responsáveis por importantes doenças infectocontagiosas em felinos. Desta forma, o objetivo do presente estudo foi investigar a prevalência e os aspectos epidemiológicos das infecções por FIV e FeLV em um hospital veterinário universitário. Realizou-se um levantamento epidemiológico dos casos de infecção pelo FIV e FeLV, diagnosticados no serviço de clínica médica do Hospital Veterinário da Universidade Federal Rural do Semi-Árido - UFERSA (Mossoró, Rio Grande do Norte, Brasil), a partir da análise dos prontuários de felinos admitidos durante o período de outubro de 2011 a julho de 2016. As fichas dos animais positivos foram revisadas para colher os dados epidemiológicos de cada animal, estilo de vida, sinais clínicos e distúrbios associados, e instituição de terapia específica. Distribuíram-se os dados em frequências absolutas e percentuais. De um total de 1.752 gatos atendidos, apenas 159 animais $(9,07 \%)$ foram submetidos ao teste para FIV e FeLV. Trinta e nove felinos (24\%) tiveram resultado reagente para FIV e apenas um gato $(0,6 \%)$ foi reagente para FeLV, o qual também estava coinfectado com o FIV. A população FIV positivo estudada foi caracterizada por ser composta, em sua maioria, por machos, sem raça definida, acima de seis anos de idade e com acesso livre à rua. 90\% desses animais estavam apresentando algum sintoma ou distúrbio clínico associado a essa retrovirose. A terapia específica para o FIV foi instituída em apenas um animal avaliado (2,56\%). Os resultados do presente trabalho caracterizaram o perfil epidemiológico dos gatos acometidos pelo FIV na cidade de Mossoró. Ressalta-se que esse conhecimento é de fundamental importância para que o clínico seja capaz de diagnosticar, manejar e atuar na prevenção de tal enfermidade.

Palavras-chave: retrovírus, FIV, FeLV, estudo retrospectivo, Felis catus 
ABSTRACT: The feline immunodeficiency virus (FIV) and the feline leukemia virus (FeLV) are responsible for important feline infectious contagious diseases. Thus, the aim to the present study was to investigate the prevalence and the epidemiological aspects of FIV and FeLV infection in a teaching veterinary hospital. An epidemiological study was performed using the cases of FIV and FeLV diagnosed by the small animal medicine department of the Veterinary Teaching Hospital from Universidade Federal Rural do Semi-Árido (UFERSA, Mossoró, Rio Grande do Norte, Brazil), from the analysis of the medical records of the cats admitted between October 2011 and July 2016. The medical records of positive animals were reviewed to collect epidemiological data from each animal, lifestyle, associated clinical signs and clinical disorders, and specific therapy institution. Data were presented as absolute and percentage frequencies. From a total of 1,752 attended cats, only 159 (9.07\%) were tested for FIV and FeLV. Thirty nine felines (24\%) were reagent for FIV and one cat $(0,6 \%)$ was reagent for FeLV, which was coinfected by FIV. The FIV positive population was composed, in its majority, by males, crossbred, with age over than 6 years old and with outdoor access. 90\% of these animals were presenting some symptom or clinical disorder related to this retrovirusis. The specific therapy for FIV was instituted in only one animal studied (2.56\%). Our results characterized the epidemiological profile of cats infected by FIV in Mossoró municipality. We emphasize that the epidemiological knowledge of feline viral immunodeficiency is very important for the clinicians to diagnosis, treat and prevent this illness.

Keywords: retrovirus, FIV, FeLV, retrospective study, Felis catus

\footnotetext{
*Author for correspondence. E-mail: artur_brihante@hotmail.com

${ }^{1}$ Autonomous Veterinarian. E-mail: vivirodolfo@ hotmail.com

${ }^{2}$ Veterinarian, Department of Animal Science, Universidade Federal Rural do Semi-Árido (UFERSA). Email: artur_brilhante@hotmail.com

${ }^{3}$ Autonomous Veterinarian. E-mail: ms.bochnakian@hotmail.com

${ }^{4}$ Professor, Doctor, Department of Animal Science, Universidade Federal Rural do Semi-Árido (UFERSA). E-mail: valeria@ufersa.edu.br

${ }^{5}$ Veterinarian, Master, Veterinary Hospital, Universidade Federal Rural do Semi-Árido (UFERSA). Email: kilder@ufersa.edu.br

http://dx.doi.org/10.5935/1981-2965.20170016
}

\section{Introduction}

The feline immunodeficiency virus (FIV) and the feline leukemia virus (FeLV) are retrovirus related to important infectious contagious diseases that affect domestic cats, which are the feline 
immunodeficiency and feline leukemia, respectively. Such infections are generically denominated retroviruses (GREENE, 2015). These etiologic agents are responsible for immunosuppressant and debilitating effects, predisposing the animal to numerous secondary illnesses, such as, bacterial and fungal infections, myeloproliferative disorders, neurological dysfunctions and neoplasia (HARTMANN, 2012). In this sense, the investigation of these pathogens is fundamental in the clinical approach of felines (LAPPIN, 2010).

It is known that these viruses present global distribution, with prevalence varying according with the location in study (GREENE, 2015). Nevertheless, epidemiological studies in Brazilian territory are still scarce. Nationally, seroepidemiological surveys showed prevalences varying from $4.14 \%$ to $16.6 \%$ for FIV, and from $1.58 \%$ to $32.5 \%$ for FeLV (HAGIWARA et al., 1997; RECHEJÚNIOR et al., 1997; SOUZA et al., 2002; TEIXEIRA et al., 2007; LARA et al., 2008; SOBRINHO et al., 2011). This variation observed had direct interference of the cat's lifestyle, and the high incidence of FIV and FeLV were especially influenced by the outdoor access and allocation in agglomerates, respectively (GREENE, 2015).
Thus, the aim of the present study was to investigate, retrospectively, the prevalence of FIV and FeLV infections and its respective epidemiological profile, in felines attended at a veterinary teaching hospital.

\section{Material and Methods}

An epidemiological study was performed, using the cases of FIV and FeLV infection diagnosed by the small animal medicine department of the Veterinary Teaching Hospital from Universidade Federal Rural do Semi-Árido (UFERSA, Mossoró, Rio Grande do Norte, Brazil).

Data were obtained from medical records of the felines admitted between October 2011 and July 2016. From the total of cats attended, a screening was made to select the animals submitted to the test to detect anti-FIV antibodies and FeLV antigens, from blood, plasma or serum samples.

The animals were tested by the Snap FIV/FeLV immunoenzymatic assay $\left(\operatorname{Idexx}{ }^{\circledR}\right.$ ) and the FIV Ab/FeLV Ag Bioeasy immunochromatographic assay (Alere $^{\circledR}$ ). Medical records were reviewed to collect individual information, such as sex, age, breed, lifestyle, associated clinical signs and clinical disorders, and specific therapy institution. Data were 
presented as absolute and percentage frequencies.

\section{Results}

In the period analyzed, a total of 1,752 cats were attended at the Veterinary Hospital from UFERSA, and 159 (9.07\%) were submitted to the test for FIV and FeLV. Thirty nine felines (24\%) were reagent for FIV, being thirty two (79\%) males and seven (21\%) females, as presented on Table 1. Only one male cat $(0,6 \%)$ was reagent for FeLV, and this animal was also coinfected by FIV.

From all animals that were positive, only twelve $(30,7 \%)$ had retroviruses as presumptive diagnosis on medical records.

According to breed, from the thirty nine FIV positive animals, thirty five (90\%) were crossbred, three $(7,5 \%)$ were Siamese and one $(2,5 \%)$ was a Persian. The FeLV positive cat was a Siamese (Table 1).

In relation to the age of the FIVpositive animals, it was observed that two cats had up to one-year old, nine (23\%) had between one and three years old, ten (25\%) had between three and six years old, and thirteen $(34 \%)$ had over six years old. The owners from five (13\%) animals did not know the precise age of their cats, and they were classified as adults. The FeLVpositive feline was on the adult category.
Considering the lifestyle of the cats from the group FIV-positive, twenty three $(60 \%)$ animals had outdoor access, while one (2\%) lived strictly indoors. The remained fifteen felines (38\%) did not have this information on the medical records. The FeLV-positive cat had outdoor access.

Regarding the clinical manifestations, thirty five $(90 \%)$ animals were presenting at least one symptom or clinical disorder related to FIV infection at the moment of the test, while four (4\%) were asymptomatic. The animal coinfected by FIV and FeLV was symptomatic and was presenting chronic kidney disease, arterial hypertension, retinal detachment and auricular chondritis. The mainly clinical manifestations and associated disorders presented by the group of FIVpositive cats are shown on Table 2.

From the thirty nine animals FIVpositive, only one $(2,56 \%)$ was submitted to the specific treatment with antiretroviral drug zidovudine.

\section{Discussion}

The FIV and FeLV were identified in several parts of the world and its prevalence vary according to the geographic area analyzed (GREENE, 2015). In relation to FIV, for example, this variation was observed in seroepidemiologic studies performed in Brazil, demonstrated from $4.14 \%$ of 
infected animals in Belo Horizonte (TEIXEIRA et al., 2007), 5.63\% in Araçatuba (SOBRINHO et al., 2011), and from $11,7 \%$ to $14.7 \%$ in cities from São Paulo State (RECHE-JÚNIOR et al., 1997; LARA et al., 2008), with the highest prevalence found in Rio de Janeiro city, with $16,6 \%$ infected cats (SOUZA et al., 2002). In the current research, we found a prevalence higher than these previous studies, and it could be explained by health status of the animals used in the study, since the majority of the cats were sick at the moment of the diagnosis. This corroborates with citations from other authors, which reported a higher prevalence on FIV in sick animals (CALDAS et al., 2000; SOUZA et al., 2002; LARA et al., 2008).

The prevalence of FeLV also presents a similar variation observed for FIV and, in Brazil, the published data show from $0.33 \%$ to $32.5 \%$ of in infected animals in different cities (HAGIWARA et al., 1997; RECHE-JÚNIOR. et al., 1997; SOUZA et al., 2002; TEIXEIRA et al., 2007; SOBRINHO et al., 2011). Based on the low incidence of FeLV infection in the work in discussion, we suggest that this virus presents a reduced prevalence in Mossoró. However, it is important to highlight that the number of animals used in the present study was not sufficient to infer the real rate of infection by FIV and FeLV, since just a small group of animals was tested, mainly, because of the nonauthorization for test execution by the owners. To the best of our knowledge, this study represents one of the first seroepidemiologic investigation for feline retrivirusis in Mossoró municipality.

The low rate of specific suspicion for FIV and FeLV on medical records was likely due to the immunosuppressant and debilitating characteristics of these viruses, which are usually the basis cause for secondary diseases. Moreover, the clinical signs manifested by the infected cats are very unspecific, and for this reason, is fundamental the knowledge of the epidemiological characteristics of this diseases to the establishment of an early presumptive diagnosis (GREENE, 2015).

In the FIV positive group, the sex of the majority of the infected cats was male, corroborating the data from other studies (TEIXEIRA et al. 2007; SOBRINHO et al. 2011; FERNANDES, 2015). This finding is justified by the male behavioral characteristics, which are commonly involved in fights for territory and mating, facilitating the infection by this retrovirus, since the virus is present in saliva and transmitted by bites (GREENE, 2015). In relation to the age of the FIVpositive group, most of the animals had 
over 6 years old, similar to the information found in the literature (RAVI et al., 2010; SILVA et al., 2014). The increased occurrence of the infection in animals of this age is expected because the virus causes a chronic infection, with a prolonged asymptomatic phase, with a late manifestation of symptoms related to the disease, usually when the animal is adult (HARTMANN et al., 2011).

Most of the FIV-positive animals from this study were crossbred, similar to the finding observed by Sobrinho et al. (2011) in Araçatuba municipality (SP), where $88,2 \%$ of the infected cats were crossbred. Nevertheless, a higher number of crossbred animals could be due to the breed profile of cats raised in the region.

Little et al. (2009) observed that the risk of FIV infection was 3.43 times higher in animals with outdoor access. Levy et al. (2008) also found that contact with the outside environment increases the chances of infection by the virus $(4.3 \%$ prevalence). These citations reinforced, for the research in evidence, the considerable frequency of FIV in animals that had outdoor access. By this it can be said that access to the street by cats is a very important factor in the spread of FIV, given its form of transmission, which occurs mainly through the bite of an infected feline (GREENE, 2015).
Regarding the clinical signs manifested, the number of symptomatic animals was superior than the asymptomatic ones, being in accordance to what was observed in other studies (CALDAS et al., 2000; LARA et al., 2008; SILVA et al., 2014). It is important to highlight that most of the symptoms and clinical disorders presented by the infected cats were similar to those described by other authors (HOSIE, 2009; SOBRINHO et al., 2011; SILVA et al., 2014).

The small number of animals submitted to specific treatment with antiretroviral drugs was due to the difficulty in acquiring these medicines. According to Brazilian rules, the drugs can only be obtained with a specific prescription from DST/AIDS program, from Ministry of Health, making impossible its obtainment and use in animals (MAZZOTTI, 2014).

In spite of the different methodologies used to test the animals, the obtained results can be considered reliable, as demonstrated by Westman et al. (2015). These authors compared efficiency of the immunoenzymatic assay and the immunochromatographic assay, and the results showed that the tests were similar and precise to detect the infection by FIV.

Only one animal was positive for the detection of FeLV antigens and for this 
reason it was not possible to determine an epidemiological profile for feline viral leukemia in this study. This animal was coinfected by FIV, and was manifesting auricular chondritis. This disorder is considered an uncommon autoimmune disease in domestic cats, characterized by inflammation and destruction of auricular cartilage, and eventually is associated with retroviral infection (COSTA et al., 2009).

Our data demonstrated that FIV might be endemic in domestic cats in Mossoró, suggesting the development of further studies to confirm this hypothesis. However, the FeLV seems to be an infectious contagious agent with low importance in this municipality.

\section{Conclusion}

The results of this research demonstrated that cats above six-year old, male and with outdoor access, presented high risk of FIV infection in the municipality of Mossoró. The epidemiological knowledge of feline viral immunodeficiency is very important for the clinicians to diagnosis, treat and prevent this illness.

\section{References}

CALDAS, A. P. F.; LEAL, E. S.; SILVA, E. F. A.; RAVAZZOLO, A. P. Detecção do provírus da imunodeficiência felina em gatos domésticos pela técnica de reação em cadeia da polimerase. Pesquisa Veterinária Brasileira, v.20, n.1, p.20-25, 2000.
COSTA, T. A.; FARIAS, M. R.; FRIESEN, R.; CAVALCANTE, C. Z.; RODIGHERI, S. M.; WERNER, J.; CRUZ, M. A. Condrite auricular felina associada à infecção pelo vírus da leucemia felina - relato de caso. MEDVEP - Revista Científica de Medicina Veterinária - Pequenos Animais e Animais de Estimação, v.7, n.20, p.103-106, 2009.

FERNANDES, A. P. R. P. Prevalência do Vírus da Imunodeficiência Felina (FIV) e do Vírus da Leucemia Felina (FeLV) e fatores de risco associados à seropositividade em gatos domésticos do Distrito de Lisboa. Vila Real, 2015. 82p. (Dissertação de Mestrado) - Universidade de Lisboa, 2015.

GREENE, C. E. Doenças infecciosas em cães e gatos. 4.ed. Rio de Janeiro: Guanabara Koogan, 2015. 1404 p.

HAGIWARA, M. K.; RECHE-JÚNIOR, A.; LUCAS, S. R. R. Estudo clínico da infecção de felinos pelo vírus da leucemia felina em São Paulo. Revista Brasileira de Ciência Veterinária, v.4, n.1, p.35-38, 1997.

HARTMANN, K. Clinical aspects of feline immunodeficiency and feline leukemia virus infection. Veterinary Immunology and Immunopathology, v.143, n.3, p.190201, 2011.

HARTMANN, K. Clinical aspects of feline retroviruses: a review. Viruses, v.4, n.11, p.2684-2710, 2012.

HOSIE, M. J. Feline immunodeficiency. ABCD guidelines on prevention and management. Journal of Feline Medicine e Surgery. v.11., n.7, p.575-584, 2009.

LAPPIN, M. R. Doenças virais polissistêmicas. In: NELSON, R. W.; COUTO, C. G. Medicina Interna de Pequenos Animais. 4.ed. Elsevier Editora: 
Rio de Janeiro, 2010, cap. 97, p. 13361350.

LARA, V. M.; TANIWAKI, S. A.; ARAUJO-JÚNIOR, J. P. Occurrence of feline immunodeficiency virus infection in cats. Ciência Rural, v.38, n.8, p.22452249, 2008.

LITTLE, S.; SEARS, W.; LACHTARA, J.; BIENZLE, D. Seroprevalence of feline leukemia virus and feline immunodeficiency virus infection among cats in Canada. Canadian Veterinary Journal, v.50, n.6, p.644-648, 2009.

MAZZOTTI, G. A. Imunodeficiência viral Felina. In: ROZA, M. R.; OLIVEIRA, A. L. A.; DE NARDI, A. B.; SILVA, R. L. M. Dia-a-dia Tópicos selecionados em especialidades veterinárias. 1.ed. Medvep:Curitiba, 2014. p.214-215.

RAVI, M.; WOBESER, G. A.; TAYLOR, S. M.; JACKSON, M. L. Naturally acquired feline immunodeficiency virus (FIV) infection in cats from western Canada: Prevalence, disease associations, and survival analysis. Canadian Veterinary Journal, v.51, n.3, p.271-276, 2010.

RECHE-JÚNIOR, A.; HAGIWARA, M. K.; LUCAS, S. R. R. Clinical study of acquired immunodeficiency syndrome in domestic cats in São Paulo. Brazilian Journal of Veterinary Research and Animal Science, v.34, n.3, p.152-155, 1997.

SILVA, F. S.; CASTRO, C. C.; FINGER, P. F.; SILVA, D. S.; TANIWAKI, S. A.; ULLMANN, L. S.; FISCHER, G.; VARGAS, G. D.; LIMA, M.; ARAÚJO-
JÚNIOR, J. P.; HÜBNER, S. O. Ocorrência do subtipo $\mathrm{B}$ do vírus da imunodeficiência felina em gatos domésticos da região sul do estado do Rio Grande do Sul, Brasil. Arquivo Brasileiro de Medicina Veterinária e Zootecnia, v.66, n.1, p.1-6, 2014.

SOBRINHO, L. S. V.; VIDES, J. P.; BRAGA, E. T.; GOMES, A. D.; ROSSI, C. N.; MARCONDES, M. Sorofrequência de infecção pelo vírus da imunodeficiência felina e vírus da leucemia felina em gatos do município de Araçatuba, São Paulo. Brazilian Journal of Veterinary Research and Animal Science, v.48, n.5, p.378-383, 2011.

SOUZA, H. J. M.; TEIXEIRA, C. H. R.; GRAÇA, R. F. S. Estudo epidemiológico de infecções pelo vírus da leucemia e/ou imunodeficiência felina, em gatos domésticos do município do Rio de Janeiro. Clínica Veterinária, n.36, p.1421, 2002.

TEIXEIRA, B. M.; RAJÃO, D. S.; HADDAD, J. P.A.; LEITE, R. C.; REIS, J. $K$. P. Occurrence of feline immunodeficiency virus and feline leukemia virus in Sheltered domestic cats of Belo Horizonte. Arquivo Brasileiro de Medicina Veterinária e Zootecnia, v.59, n.4, p.939-942, 2007.

WESTMAN, M. E; MALIK, R; HALL, E; SHEEHY, P. A; NORRIS, J. M. Determining the feline immunodeficiency virus (FIV) status of FIV-vaccinated cats using point-of-care antibody kits. Comparative Immunology, Microbiology and Infectious Diseases, v.42, p.43-52, 2015. 
Table 1. Epidemiological characterization of positive felines for the immunodeficiency virus and leukemia virus attended at the Veterinary Hospital from UFERSA, between October 2011 and July 2016.

\begin{tabular}{lcc}
\hline Sex & Number of animals & Percentage (\%) \\
Male & 32 & 79 \\
$\quad$ Female & 7 & 21 \\
Breed & 35 & \\
$\quad$ Crossbred & 3 & 90 \\
Siamese & 1 & 7,5 \\
Persian & & 2,5 \\
Age $\quad 2$ & \\
Up to 1 year & 2 & 5 \\
1 - 3 years & 9 & 23 \\
3 - 6 years & 10 & 25 \\
Over 6 years & 13 & 34 \\
Adult* & 5 & 13
\end{tabular}

*Animals were put in this category when owners did not know the precise age of their cats. 
Table 2. Mainly symptoms and clinical disorders presented by the positive felines for the immunodeficiency virus, attended at the Veterinary Hospital from UFERSA, between October 2011 and July 2016.

\begin{tabular}{lcc}
\hline Symptoms/Clinical disorders & Number of animals & Percentage (\%) \\
\hline Oral lesions & 10 & 25,6 \\
Neoplasia & 6 & 15,4 \\
Dysphagia & 12 & 30,7 \\
Weight loss & 6 & 15,4 \\
Diarrhea & 3 & 7,5 \\
Ocular disorders & 3 & 7,5 \\
Respiratory disorders & 5 & 12,8 \\
Urinary tract disorders & 3 & 7,5 \\
Auricular disorders & 3 & 7,5 \\
Others & 4 & 10,2 \\
\hline
\end{tabular}

